\title{
Retention factors of experienced Malay male Architects in Malaysian architectural design consultant firms in the Klang Valley, Malaysia
}

\author{
Ismah Sumayyah Mohd Amar ${ }^{1, *}$, and Mohd Hisham Ariffin ${ }^{2}$ \\ ${ }^{1}$ Centre of Postgraduate Studies (Student, Master in Integrated Construction Project Management programme), Faculty of Architecture, \\ Planning and Surveying, Universiti Teknologi MARA, Shah Alam, Selangor, Malaysia. \\ ${ }^{2}$ Faculty of Architecture, Planning and Surveying, Universiti Teknologi MARA, Shah Alam, Selangor, Malaysia.
}

\begin{abstract}
The Malaysian construction industry suffers from a high rate of talent attrition within architecture design consultant firms which hinders these firms from competing locally and globally. This talent attrition hinders strategic nurturing of employees needed to sustain the firms' involvement in the global market. This paper reports the findings of an investigation into the factors that contribute to employee retention of a purposive sample of ten male professional Malay Architects in Malaysian architecture consulting firms in the Klang Valley. It explored the reasons for respondents remaining with their employers through data collected from qualitative interviews. The data in the form of interview transcripts, interview memos and analysis memos were analyzed using category coding to generate meaning units and categories of employment retention. The analysis was based upon Alderfer's ERG motivation theory and intrinsic motivations. It was found that existence needs (convenience, physiological needs, material security), relatedness needs (group belongingness, social needs, family obligation, friendship obligation, employment group obligation, social obligation, and social esteem), growth needs (self esteem and self-actualization) and intrinsic motives (choices, progress, competence and meaningfulness) underlie the employment retention of the respondents. The research findings provide insights about Malay male Architects employment retention factors in Malaysian architecture consulting firms.
\end{abstract}

\section{Introduction}

Malaysia is undergoing a major economic transformation through various programmes such as the Construction Industry Transformation Programme (CITP) to become a high income nation in the near future. Architecture is one of the professions listed as skilled, sought-after, and strategic yet its' supply does not meet the industry's needs [1]. The high rate of employees' turnover in architecture also decreases the opportunities for the employees' creativity to be strategically nurtured in the firm. CITP's targets for Malaysian construction related companies to export their services in the global market are hindered because there is high rate of talent attritions in architectural firms that are primarily small and sole proprietorships and partnerships [2]. These firms are unable to provide clear career progression paths and ideal work environments for employees. Participation in foreign markets requires more talented and efficient employees to increase the firms' competitiveness. Efficiency is hindered when there are relatively transient employees. These issues motivate this dissertation research [3] to uncover the factors that contribute to employee retention of Malay Architects in Malaysian architecture consulting firms.

\section{Past Researches}

There are seven past researches in the period between years 2013-2017 that are related to the employee retention factors. The findings can be categorised into job satisfaction [4-9] and organisational commitments [7-10]. The employees' feelings towards performing the job are measured as satisfaction whether in positive or negative perspectives [11] which can give impacts to the employees' productivity and performance [7]. However, the satisfaction towards job is measured by individual rather than group satisfaction [12]. The job satisfaction may lead to organisational commitment and affect the employees' loyalty towards job [7, 13]. The dimensions of job satisfaction related factors in the private banking sector of India are ranked as career prospects, control, mentoring and guidance, employee engagement programs and co-operation [5]. Compensation, appraisal, training and career development are the most important factors that influenced job satisfaction to improve employees' loyalty towards their jobs and organisations in Pakistan banking sector [7].

The organizational commitment of project managers in China construction industry are weakly correlated with twelve job satisfaction variables $(p<0.01)$ which are

\footnotetext{
* Corresponding author: ismahamar@gmail.com
} 
stockholder, supervisor, re-education, autonomy, promotion, co-workers, communication, authority, recognition, work conditions, financial reward and company policy [6]. Long working hours, heavy workloads, lack of interest in construction industry, low financial rewards and limited job prospects negatively influenced the Nigerian student commitment to remain in architectural university programmes [4].

The organisational commitment is not affected by job satisfaction [7] but it is more about employees' feeling towards the organisation [14] and the capability of organisation to satisfy the employees [15]. This feeling leads to positive behaviours among the employees [16]. However, the organisational commitment has greater impacts on job loyalty and could be achieved through three dimensions of affective, continuance and normative commitments [17]. Thus, employee loyalty could be defined as synonymous of organisational commitment. Identification, attachment, feelings of belonging, length of service, commitment, participation, psychological contract, trust and appraisal are the elements of job satisfaction and organizational commitment related to organisational performance [8]. Bonus, job security, promotion, supervisor praise, respect and friendly co-workers are positively associated with loyalty towards job among employees in six former socialist republics [9].

There is only one relevant research in the period between years 2013-2017 conducted in the Malaysian construction field [10]. However, it investigated the effect of conflicts between personal and organizational values on organisational commitment through a questionnaire survey of 428 professional project consultants in Malaysia construction sector. Comparative and hierarchical regression analysis showed that a high level of value conflicts between personal and organizational values in the construction organizations negatively affected the employees' commitment $(p<0.05)$. There are no reported studies on retention factors of Malay male Architects in Malaysian architecture consulting firms in scholarly literature.

\section{Methodology}

An exploratory qualitative interview research is used. The purposive sample of ten respondents in Klang Valley consisted of male Malay Professional Architects employed in Malaysian architecture consulting firms. Six respondents are in middle management level while the remaining in the supervisory level. Seven respondents involved in design and project management while others worked in either one. The respondents have eight years minimum working experience in construction industry and have ages above 30 years. All are married except for respondents 4, 5, 6, 8 and 10 .

The first author did face to face interviews with the respondents. The respondents were asked to explain their reasons in staying longer in Malaysian architecture consulting firms. The interviews were audio recorded and transcribed for analysis. Qualitative category coding is a qualitative content analysis technique whereby categories and meaning units are generated from the transcript analyses based upon a chosen theoretical base. The Alderfer's ERG motivational theory and intrinsic motivation are the analytical bases. The second author reviewed the analysis to improve the robustness of the analysis.

\section{Findings}

The findings indicated that the retention categories are existence needs, relatedness needs, growth needs, and intrinsic motives highly affect the respondents' retention factors in the architecture firms. Existence needs are the goals to obtain physiological needs (basic needs), material security (protection from threats) and convenience (comfort) (Table1). All respondents mentioned about convenience as their retention factors and some cited physiological needs and material security.

For me, the reasons are the working culture and specialization of which part you want to practice...I forgot to quote, the proximity of the office location is important. If we not around the neighborhood of the office, we will bring the stress of traffic jam come into the office...I will not have flexibility of time that I have to day. The time is precious. For me, it's precious to see my children growing up which will be once in lifetime. Interviewee no. 2

Table 1. Definition of Existence Needs Category and Meaning Units.

\begin{tabular}{|l|l|}
\hline \multicolumn{1}{|c|}{ CATEGORY } & \multicolumn{1}{c|}{ MEANING UNIT } \\
\hline $\begin{array}{l}\text { EXISTENCE } \\
\text { NEEDS: }\end{array}$ & $\begin{array}{l}\text { PHYSIOLOGICAL NEED: } \\
\text { The basic physiological needs } \\
\text { that come from an organizational } \\
\text { setting such as adequate salary, } \\
\text { veeds related to } \\
\text { obtaining various } \\
\text { forms of } \\
\text { physiological and } \\
\text { material } \\
\text { requirements. }\end{array}$ \\
\cline { 2 - 2 } $\begin{array}{l}\text { Fulfillment of } \\
\text { existence needs } \\
\text { gives feelings of } \\
\text { physical and } \\
\text { material safety and } \\
\text { convenience. }\end{array}$ & $\begin{array}{l}\text { MATERIAL SECURITY: } \\
\text { The needs for protection of } \\
\text { material possessions and the } \\
\text { person from physical threats and } \\
\text { losses. These possessions and } \\
\text { physical threats include security } \\
\text { of employment and resources, } \\
\text { bonuses, benefits, company } \\
\text { policy.. }\end{array}$ \\
\cline { 2 - 2 } & $\begin{array}{l}\text { CONVENIENCE: } \\
\text { The needs relate to individual } \\
\text { physical ease and emotional } \\
\text { comfort such as happy work } \\
\text { environment, convenient location, } \\
\text { good working culture, and work } \\
\text { preferences }\end{array}$ \\
\hline
\end{tabular}

Relatedness needs are related to meaningful social relationships that lead to satisfaction, social esteem and social obligation motivations. These needs consist of group belongingness, social needs, family obligation, 
friendship obligation, employment group obligation, social obligation, and social esteem (Table 2). The respondents mentioned combinations of these meaning units while social obligation is only cited by the first interviewee. Employment group obligation to fulfilling responsibilities of fellow employees, subordinates and employer are cited by all respondents.

So, we respect each other's opinions whether it came from technical persons (or not). We still have to respect their contributions (whether they are) technical persons or top management. For example, technicians contribute the drawings. Sometimes we the top management do not know the problems they are facing. So, they bring these problems up in the meetings which help us in management not to repeat the problematic actions and try to work in another way. Interviewee no. 4

Table 2. Definition of Relatedness Needs Category and Meaning Units.

\begin{tabular}{|c|c|}
\hline CATEGORY & MEANING UNIT \\
\hline \multirow{6}{*}{$\begin{array}{l}\text { RELATEDNESS } \\
\text { NEEDS: } \\
\text { Needs that are } \\
\text { related to } \\
\text { meaningful social } \\
\text { relationships } \\
\text { Satisfaction is } \\
\text { achieved with the } \\
\text { sense of } \\
\text { belongingness by } \\
\text { mutually sharing } \\
\text { their thoughts and } \\
\text { feelings. It } \\
\text { increases an } \\
\text { individual's social } \\
\text { esteem and } \\
\text { motivates the } \\
\text { individual to fulfill } \\
\text { his social } \\
\text { obligations. }\end{array}$} & $\begin{array}{l}\text { GROUP BELONGINGNESS: } \\
\text { The needs for interpersonal } \\
\text { relationships which lead to sense } \\
\text { of group belongingness, } \\
\text { friendship, acceptance, and } \\
\text { support within the organization. }\end{array}$ \\
\hline & $\begin{array}{l}\text { SOCIAL NEEDS: } \\
\text { The needs for opportunity to } \\
\text { interact and communicate with } \\
\text { others such as interpersonal } \\
\text { relationship, affiliation and } \\
\text { supervision. }\end{array}$ \\
\hline & $\begin{array}{l}\text { FAMILY OBLIGATION: } \\
\text { The needs associated with } \\
\text { fulfilling responsibilities for the } \\
\text { family members. }\end{array}$ \\
\hline & $\begin{array}{l}\text { FRIENDSHIP OBLIGATION: } \\
\text { The needs associated with } \\
\text { fulfilling responsibilities for } \\
\text { friends. }\end{array}$ \\
\hline & $\begin{array}{l}\text { EMPLOYMENT GROUP } \\
\text { OBLIGATION: } \\
\text { The needs associated with } \\
\text { fulfilling responsibilities fellow } \\
\text { employees, subordinates and } \\
\text { employer. }\end{array}$ \\
\hline & $\begin{array}{l}\text { SOCIAL OBLIGATION: } \\
\text { The needs associated with } \\
\text { fulfilling responsibilities required } \\
\text { to fulfill other persons social } \\
\text { needs (excluding family, friends } \\
\text { and employment group). }\end{array}$ \\
\hline
\end{tabular}

\begin{tabular}{|l|l|}
\hline & SOCIAL ESTEEM: \\
RELATEDNESS & The needs associated with having \\
meEDS (contd.) & valual feelings of high personal \\
& interactions with other persons. \\
& The feelings include mutual \\
& recognition and admiration, \\
& respect and affection with others. \\
\hline
\end{tabular}

Growth needs are the desires of a person to have creative and productive effects for himself and his environment through self-esteem (esteem depends on internal cues) and self-actualization (opportunities for development) (Table 3). Self-esteem is cited by all respondents while only one respondent did not mention about self-actualization.

\begin{abstract}
It is about on how you want to be a businessman in architecture consultancy practice... So by staying longer in this company, it will develop my 'personality' (that can contribute) towards attracting (new) projects. Interviewee no. 10
\end{abstract}

Table 3. Definition of Growth Needs Category and Meaning Units.

\begin{tabular}{|c|c|}
\hline CATEGORY & MEANING UNIT \\
\hline $\begin{array}{l}\text { GROWTH } \\
\text { NEEDS: } \\
\text { Needs related to } \\
\text { confidence and } \\
\text { desires of a person } \\
\text { to have creative } \\
\text { and productive } \\
\text { environment for } \\
\text { self enhancement. } \\
\text { Satisfaction of }\end{array}$ & $\begin{array}{l}\text { SELF ESTEEM: } \\
\text { The needs associated with having } \\
\text { personal esteem which depends } \\
\text { on the internal cues which a } \\
\text { person obtains from producing } \\
\text { personal real capacity, } \\
\text { achievement and independence. } \\
\text { These cues include autonomy, } \\
\text { responsibility and a chance to be } \\
\text { creative. }\end{array}$ \\
\hline $\begin{array}{l}\text { growth needs } \\
\text { occurs when a } \\
\text { person utilizes his } \\
\text { fully capacities and } \\
\text { develop new } \\
\text { capabilities. }\end{array}$ & $\begin{array}{l}\text { SELF-ACTUALIZATION: } \\
\text { The needs associated with having } \\
\text { opportunities for and tangible } \\
\text { acknowledgement of unique } \\
\text { personal development and growth } \\
\text { such as titles, promotions, } \\
\text { advancement. }\end{array}$ \\
\hline
\end{tabular}

Intrinsic motives refer to the internal forces that make the individual to engage in an activity that gives positive and pleasing emotions. These emotions are grouped in four meaning units namely choices, progress, competence and meaningfulness (Table 4). Five respondents cited all these meaning units while others cited some of these meaning units. There were no meaning units that were cited by all the respondents.

The distribution of the meaning units and categories of the respondents are shown in Table 5. 
Table 4. Definition of Intrinsic Motives Category and Meaning Units.

\begin{tabular}{|c|c|}
\hline CATEGORY & MEANING UNIT \\
\hline \multirow{4}{*}{$\begin{array}{l}\text { INTRINSIC } \\
\text { MOTIVES: } \\
\text { The internal forces } \\
\text { that make the } \\
\text { individual to } \\
\text { engage in an } \\
\text { activity that gives } \\
\text { positive and } \\
\text { pleasing emotions }\end{array}$} & $\begin{array}{l}\text { CHOICE: } \\
\text { Needs for positive emotions due } \\
\text { to having variety of choices and } \\
\text { freedom to chose based on } \\
\text { individual preference. }\end{array}$ \\
\hline & $\begin{array}{l}\text { PROGRESS: } \\
\text { Needs for positive emotions } \\
\text { arising from having development, } \\
\text { advancement, and improvement } \\
\text { towards the person's goal. }\end{array}$ \\
\hline & $\begin{array}{l}\text { COMPETENCE: } \\
\text { Needs for positive emotions due } \\
\text { to having the ability and } \\
\text { condition that allows the } \\
\text { individual to perform. }\end{array}$ \\
\hline & $\begin{array}{l}\text { MEANINGFULNESS: } \\
\text { Needs for positive emotions due } \\
\text { to engaging in activities that have } \\
\text { great value and significance to the } \\
\text { person. }\end{array}$ \\
\hline
\end{tabular}

\section{Discussion}

All the Malay male architect respondents require balance of existence needs (convenience), relatedness needs (employment group obligation) and growth needs (self-esteem) to stay employed in Malaysian architecture consulting firms. Thus, this implies that salary, increments of salary, bonuses and benefits could not ensure the employees' retention. Researches in developing countries found work enjoyment [4, 5, 9], working environment $[6,8,9,10]$, and flexibility of time $[4,5,8]$ as employment retention factors. This research found additional retention factor i.e. tolerable officehome commuting and need for work-life balance.

Tolerable office-home commuting is a retention factor possibly because the respondents are working in the Klang Valley where traffic congestion is rife. Shorter commuting times are more convenient and less stressful. In addition, the respondents are generation- $Y$ employees who seek to have work-life balance $[18,19]$.

The nature of architecture work sometimes requires these architects to work overtime without extra payments. The workload is high compared to the recommendations by UNESCO [20]. Yet, they were able to sustain work-life balance due to shorter commuting times and a tolerable amount of work load that do not take time away from their family and social obligations.

The respondents said that their reluctance to leave their employers is due to their obligations to their employers and subordinates to engage in the projects assignments to the finish. This is probably due to the respondents being indoctrinated with professionalism that stresses on altruistic work-related commitment to their projects' stakeholders. This finding concurs with
Table 5. Respondents' Categories and Meaning Units.

\begin{tabular}{|c|c|c|c|c|c|c|c|c|c|c|}
\hline \multirow{2}{*}{$\begin{array}{l}\text { Category of } \\
\text { Employment } \\
\text { Retention }\end{array}$} & \multirow[t]{2}{*}{ Meaning Unit } & \multicolumn{8}{|c|}{ Respondent (shading shows citing) } & \multirow{2}{*}{$\begin{array}{l}\text { No. of } \\
\text { persons } \\
\text { citing }\end{array}$} \\
\hline & & 1 & 2 & 3 & 5 & 6 & & 8 & & \\
\hline \multirow[t]{3}{*}{ Existence Needs } & $\begin{array}{l}\text { Physiological } \\
\text { Needs }\end{array}$ & & & & & & & & & 6 \\
\hline & Material Security & & & & & & & & & 5 \\
\hline & Convenience & & & & & & & & & 10 \\
\hline \multirow[t]{7}{*}{$\begin{array}{l}\text { Relatedness } \\
\text { Needs }\end{array}$} & $\begin{array}{l}\text { Group } \\
\text { Belongingness }\end{array}$ & & & & & & & & & 9 \\
\hline & Social Needs & & & & & & & & & 9 \\
\hline & $\begin{array}{l}\text { Family } \\
\text { Obligations }\end{array}$ & & & & & & & & & 7 \\
\hline & $\begin{array}{l}\text { Friendship } \\
\text { Obligations }\end{array}$ & & & & & & & & & 6 \\
\hline & $\begin{array}{l}\text { Employment } \\
\text { Group } \\
\text { Obligations }\end{array}$ & & & & & & & & & 10 \\
\hline & Social Obligations & & & & & & & & & 1 \\
\hline & Social Esteem & & & & & & & & & 6 \\
\hline \multirow[t]{2}{*}{ Growth Needs } & Self Esteem & & & & & & & & & 10 \\
\hline & Self Actualization & & & & & & & & & 9 \\
\hline \multirow[t]{4}{*}{ Intrinsic Needs } & Choice & & & & & & & & & 7 \\
\hline & Progress & & & & & & & & & 6 \\
\hline & Competence & & & & & & & & & 5 \\
\hline & Meaningfulness & & & & & & & & & 8 \\
\hline
\end{tabular}

research findings on professional project consultants in Malaysian construction industry [10], project managers in China construction industry [6], and Central Asia and Soviet republic employees [9]. Our findings also concur with the critical literature review by Guillon and Cezanne [8] on relationship of job loyalty and organisational performance. Their review indicated that commitment lead to employee retention.

Growth needs category is cited by most respondents towards their retention. However, the only research [10] conducted on employee retention among professional project consultants in Malaysian construction industry did not mention about the growth needs. But, research [6] conducted on project managers in China construction industry found that fulfilling employees' growth needs is required to retain employees. The findings are supported by researches [5, $7,9]$ conducted in various industries and countries. Self- 
actualisation as job loyalty factor is supported by the findings of a research on teachers in Ghana rural schools [4].

The intrinsic motives findings concurred with the research [9] conducted in six different countries and diverse occupations. The respondents cited meaningfulness and choice which related on the opportunity rather than accomplishment [21]. The findings also imply that the respondents are focused on the purposes (sense of meaningfulness and progress) rather than activities (sense of choice and competence) itself. This might be due to the professional and specialised nature of architectural work within a construction project team. Hence, complete commitment to the design and management tasks is needed to fulfil the architectural firm's contributions to the project outcome. This in turn provides the positive emotions associated with fulfilling one's professional obligations.

The findings suggest that architectural firm employers can increase employment retention if their employees can get work life balance, a sense of commitment to and professionalism in the work place, work satisfaction and professional growth from their workplace. A survey research is needed to determine the generalizability of these findings.

\section{Conclusion}

The balance of Malay male Architects employees' existence needs (convenience), relatedness needs (employment group obligation) and growth needs (selfesteem) is required for Malaysian architecture consulting firms to retain them. These employees have intrinsic motives as well as extrinsic needs unique to their architecture employment situations. Our research findings provide insights about Malay male Architects employment retention factors in Malaysian architecture consulting firms. These insights are absent in scholarly literature. It can thus guide future quantitative researches for generating generalised findings on the retention factors of different sample of respondents, different gender or races of Architects in Malaysian architecture consulting firms and from the different sizes of firms.

\section{References}

1. C. S. CSC, The critical occupational list report, Petaling Jaya: Talent Corp (2016/2017)

2. CIDB. Construction Industry Transformation Programme 2016-2020. Kuala Lumpur: CIDB Malaysia (2015)

3. I. S. M. Amar. Employment attrition and retention of Malay male architects in architectural design firms in the Klang Valley, Malaysia. Unpublished dissertation, Masters in Integrated Construction Project Management, Universiti Teknologi MARA, Shah Alam, Malaysia (2018)

4. C. O. Adeokun, Exploring the link betwen motivation for course-choice and retention in the architectural profession: Student's perspectives, Mediterr. J. Soc. Sci 6(6), 191-201 (2015)

5. S. P. Nijhawan \& D. P. Nijhawan, New key to employee retention-intrinsic motivation: A study of private banking sector of India, JIR 2(1), 90-95 (2014)

6. Y. $\mathrm{Xu}, \mathrm{D}$. Wang, \& C. Liu, Factors affecting commitment and satisfaction of project managers in the construction industry. (IEEE) International Conference: Management Science and Engineering (ICMSE), 2072-2077, Harbin: Institute of Electrical and Electronics Engineers (IEEE) (2013)

7. M. Uzair, W. Razzaq, M. Sarfraz, \& Q. A. Nisar, Impact of HR practices on employee loyalty and commitment: Mediating role of job satisfaction, IJME 9(2), 1067-1073 (2017)

8. O. Guillon, \& C. Cezanne, Employee loyalty and organizational performance: A critical survey. JOCM 27(5), 839-850 (2014)

9. S. Linz, L. K. Good, \& M. Busch, Promoting worker loyalty: an empirical analysis. INT. J. Manpower 36(2), 169-191 (2015)

10. B. Panahi, \& E. Moezzi, Value conflicts and organizational commitment of internal construction stakeholders. ECAM 24(4), 554-574 (2016)

11. I. Oplatka, \& R. Mimmon, Women principals' conception of job satisfaction and dissatisfaction: An alternative view, Int. J. Leader. Educ 11(2), 135153 (2008)

12. E. A. Locke, Handbook of industrial and organisational psychology, Chicago: Rand McNally (1976).

13. O. Janssen, Fairness perceptions as a moderato in the curvilinear relationships between job demands, job performance and job satisfaction. Acad. Manage. J 44(5), 1039-1050 (2001)

14. C. A. O'Reilly, \& J. A. Chatman, Organisational commitment and psychological attachment: The effcts of compliance, identification, and internalization on prosocial behaviour. J. Appl. Psychol 71(3), 492-499 (1986)

15. A. A. Ketchand, \& J. R. Strawser, Multiple dimensions of organisational commitment: implications for future accounting research, BRIA 33(1), 221-51 (2001)

16. S. I. S. Al-Hawary, \& H. M. A. Alajmi, Organizational commitment of the employees of the Ports Security Affairs of the state of Kuwait: The impact of HR management practices, IJ-AREMS 52-78 (2017)

17. N. J. Allen, \& J. Meyer, A three component conceptualization of organisational commitment, HRMR 1(1), 61-89 (1991)

18. A. Queiri, W. F. W. Yusoff, \& N. Dwaikat, Explaining generation-Y employees' turnover in Malaysia context, Asian Soc. Sci 11(10), 126-138 (2015) 
19. N. H. Zulbahari, \& R. Alias, Malaysia's trend of employment turnover: study on generation $\mathrm{Y}$, JMMR 3(11), 1-13 (2014)

20. C. Chin, Nation builders wanted. Retrieved from https://www.thestar.com.my/news/nation/2016/02/2 8/nation-builders-wanted-malaysias-dream-ofbecoming-a-highincome-nation-by-2020-couldcrumble-if-we-d/ (2016, February 28)

21. K. W. Thomas, \& B. A. Velthouse, Cognitive elements of empowerment an interpretive model of intrinsic task motivation, Acad. Manage Rev 15(4), 666-681 (1990). 